Published by Al-Nahrain College of Medicine P-ISSN 1681-6579

E-ISSN 2224-4719

Email: iraqijms@colmed-alnahrain.edu.iq http://www.colmed-alnahrain.edu.iq http://www.iraqijms.net

\title{
Frequency of Human Cytomegalovirus and Human Herpesvirus-1 Antigens in Product of Conceptus Tissues of Pregnant Women with Spontaneous Abortion
}

\author{
Areej A. Hussein ${ }^{1}$ PhD, Post Doc, Sawsan T. Salman² FICMS, CABOG, Basim M. Khashman ${ }^{3}$ MSC \\ ${ }^{1}$ Dept. of Microbiology, ${ }^{2}$ Dept. of Obstetrics and Gynecology, College of Medicine, University of Diyala, Baqubah, Iraq, \\ ${ }^{3}$ Iraqi National Cancer Research Center, University of Baghdad, Iraq.
}

\begin{abstract}
Background Viral infections in pregnancy are major causes of maternal and fetal morbidity and mortality. Infections develop in the neonate transplacentally, perinatally or postnatally.

Objective To determine the frequency of cytomegalovirus and human herpesvirus-1antigens in product of conceptus tissues of pregnant women with spontaneous abortion and to study the association of the various socio-demographic and antenatal factors.

Methods Fifty (50) product of conceptus tissues samples were collected during the period from September 2013 till April 2014 from pregnant women with spontaneous abortion attended at Al-Batool Teaching Hospital for Maternity and Children in Baqubah city. All sociodemographic and antenatal characteristics such as age, education level, economic level, occupation, residence, gestational age, history of abortion and gravity were recorded. Human cytomegalovirus and human herpes virus-1 antigens were detected by immunohistochemistry technique in Department of Microbiology, College of Medicine, University of Diyala.

Results Among 50 formalin-fixed, paraffin embedded product of conceptus tissues blocks, the results showed that positivity frequency of human cytomegalovirus and human herpesvirus-1 antigens were $36 \%$ (18 out of 50 ) for each one. Patients age varied from (15-45) years with mean of 29.48 years. The highest rate of viral infection was diagnosed in the age 26-35 years. Multiple variables regarding frequencies of cytomegalovirus and human herpesvirus-1antigens simultaneously, was evaluated, and none of the variables had significant difference.

Conclusion Human cytomegalovirus and human herpesvirus-1 seems to play a significant role in first trimester pregnancy loss and its infection rate is comparable with that in the other countries, also pregnant women in Baqubah city may have the risk for acquiring viral infection during pregnancy and consequently adverse pregnancy outcomes.

Keywords Abortion, cytomegalovirus, human herpes virus, immunohistochemistry, pregnant women Citation Areej A. Hussein, Sawsan T. Salman, Basim M. Khashman. Frequency of human cytomegalovirus and human herpesvirus-1 antigens in product of conceptus tissues of pregnant women with spontaneous abortion. Iraqi JMS. 2017; Vol. 15(1): 94-102. doi: 10.22578/IJMS.15.1.12
\end{abstract}

List of abbreviation: $\mathrm{B} 19 \mathrm{~V}=$ Human parvovirus $\mathrm{B} 19, \mathrm{HCMV}=$ Human cytomegalovirus, HHSV-1/2 = Human herpes simplex virus, PBS $=$ Phosphate buffers saline

\section{Introduction}

pontaneous abortion or pregnancy loss is the natural death of an embryo or fetus before it is able to survive independently

(1). The cutoff of 20 weeks of gestation after 
which, fetal death is known as a stillbirth (2). There are several factors related to spontaneous abortion, such as genetic abnormalities and infections (3). Many studies showed virus such as human cytomegalovirus (HCMV), human herpes simplex virus (HHSV1/2), human parvovirus B19 (B19V), enterovirus, adenovirus, and varicella-zoster virus are causative agents of spontaneous abortion (4-6).

Herpesviruses comprise the largest family of viruses with oral manifestations. Eight types of herpesvirus are known to be pathogenic in human (7).

Human cytomegalovirus is the most common congenital infection, occurring in $0.3-1 \%$ of all live births worldwide. It may lead to permanent disabilities in the unborn child, such as deafness, blindness and mental impairments (8). Primary HCMV infection results in life-long latent infection, and although congenital infection after reactivation and re-infection with a different HCMV strain may occur, the risk of congenital infection is highest for seronegative women ${ }^{(9,10)}$.

Another virus that could be implicated in recurrent abortion is herpes simplex. Genital herpes is the result of infection by human herpes simplex virus type 2 (HHSV-2) and to a lesser extent human herpesvirus type 1 (HHSV1). There has been a rise in the prevalence of genital human herpesvirus infections in both industrialized and developing countries. The main factors attributed to the spread of human herpesvirus include asymptomatic virus shedding and under recognition and underdiagnoses of the disease. At the level of the individual patient, genital herpes is associated with significant psychological morbidity and complications such as neonatal herpes, the result of transmission of HHSV from mother to baby ${ }^{(11,12)}$. The incidence of asymptomatic cervical HHSV-2 infections was considerably higher in patients with a history of spontaneous abortion with a possible etiologic connection between human herpesvirus and spontaneous abortion (13).
Serologic assays were not very useful for the elucidation of the role of human herpesvirus in inducing spontaneous abortions, although they indicate that the state of pregnancy predisposes to human herpesvirus reactivation (14).

So, this study aims to determine the frequency of HCMV and HHSV-1 antigens in product of conceptus tissues of pregnant women with spontaneous abortion and study the possible association of the various socio-demographic and antenatal factors.

\section{Methods}

\section{Study design}

This cross-sectional study was done during the period from September 2013 to April 2014 in Al-Batool Teaching Hospital for Maternity and Children, pregnant women with spontaneous abortion were enrolled in the study. The age of women ranged from (15-45) years. Product of conceptus tissues samples were collected from all participants after the abortion and all sociodemographic and antenatal characteristics such as age, education level, economic level, occupation, residence, gestational age, history of abortion and gravidity were recorded.

\section{Ethical approval}

The proposal was reviewed and approved by College of Medicine; University of Diyala, permission to conduct this study was obtained from Al-Batool Teaching Hospital for Maternity and Children administrator in Baqubah city, Diyala, Iraq. Participants were also informed that they have full right to discontinue or refuse to participate in this study.

\section{Sampling and processing}

From each participating woman, data were obtained and product of conceptus tissues sample were collected in a clean container with $10 \%$ formaldehyde and used to prepared formalin fixed paraffin embedded tissues block, then immunohistochemistry used for the detection of anti-cytomegalovirus ppm 
antibody or late Ag (CMV- Cat. No. ab 49214. Cambridge Science Park - England) and specific human herpes virus type 1 envelop antigen (HHV-1 - Cat. No. ab9533. Cambridge Science Park - England).

According to manufacturer's protocol. The slides were deparaffinized and rehydrated by xylene and serially graded alcohol for 5 minutes each and then distill water. Endogenous peroxidase activity was blocked by $3 \%$ hydrogen peroxide for 10 minutes. Slides were washed in phosphate-buffered saline. Then treated with protein block, incubated at $37{ }^{\circ} \mathrm{C}$ for 5 minutes and washed with phosphate buffers saline (PBS). Primary antibody was applied to cover slides and incubated for 1 hours in humidity chamber at $37{ }^{\circ} \mathrm{C}$ (Primary Antibody was prepared at dilution 1:100). Slides were rinsed gently in PBS. The secondary antibody was added for 10 minutes at room temperature, followed by the addition of Streptavidine-HRP antibodies for 10 minutes at $37{ }^{\circ} \mathrm{C}$. After washing, samples were stained with diluted liquid DAB for 15-45 minutes at room temperature. Slides were counterstained with hematoxylin for 30 second and washed well in running tap water, then dehydrated and mounting with permanentmounting medium (DPX), examined under light microscope was finally done.

\section{Statistical analysis}

Chi-square test were used to analyzed the data of present study and P-values $<0.05$ were considered statistically significant.

\section{Results}

This study comprised of 50 pregnant women with spontaneous abortion among these women minimum age was 15 years and maximum 45 years. Mean age of the aborted women was 29.48 years; majority of pregnant women with spontaneous abortion were among the age group 15-35 years. According to education level most participants had primary school education 28 (56\%), regarding occupation and economic level, high percentages were recorded within housewives and intermediate level and they are accounted $86 \%$ and $78 \%$ respectively. There were highly significant differences $(P<0.05)$ noticed between pregnant women with spontaneous abortion and different parameters while nonsignificant correlation noticed only among age groups as shows in table (1).

The number of pregnant women with spontaneous abortion in the first trimester was 41 cases (82\%) while in the second trimester were 9 cases (18\%). There was highly significant differences $(\mathrm{P}<0.05)$ noticed as shows in table (2). Second time abortion was very high 23 (46\%) compared with other, multiparty in was higher among aborted women and they were accounted 31 (62\%), but the difference was not significant.

Immunohistochemistry results have demonstrated that 18 out of 50 (36\%) in product of conceptus tissues of aborted women cases were positive for HCMV and HHV-1, but statistical analysis showed insignificant difference at $\mathrm{P}>0.05$ as shown in table (3) and figure (1).

Table (4) and (5) demonstrate the correlation between expression of HCMV and HHV-1 with different variables. The results of present study showed that there were no significant differences between immunohistochemistry expression of both HCMV and HHV-1 with age, education level, economic level, occupation, residence, gestational age, last history of abortion and gravidity. Based on Chi-square test of analysis and Fischer exact test. 
Table 1. Socio-demographic characteristics of subjects

\begin{tabular}{ccccc}
\hline \multicolumn{2}{c}{ Variable } & Number & Percentage & $\begin{array}{c}\text { Comparison of } \\
\text { Significance } \\
\text { P-value }\end{array}$ \\
\hline \multirow{2}{*}{ Age stratum } & $15-25$ years & 19 & $38 \%$ & \\
& $26-35$ years & 19 & $38 \%$ & 0.375 \\
& $36-45$ years & 12 & $24 \%$ & \\
Education level & Illiterate & 8 & $16 \%$ & 0.000 \\
& Primary School & 28 & $56 \%$ & \\
& Secondary School & 6 & $12 \%$ & 0.000 \\
Occupation & Tertiary level & 8 & $16 \%$ & 0.000 \\
& Working & 7 & $14 \%$ & \\
\hline \multirow{2}{*}{ Economic level } & Housewives & 43 & $86 \%$ & 0.002 \\
& Low & 8 & $16 \%$ & \\
\hline \multirow{2}{*}{ Residence } & Intermediate & 39 & $78 \%$ & \\
\hline Total & High & 3 & $6 \%$ & $72 \%$ \\
\hline
\end{tabular}

Table 2. Antenatal characteristics of subjects

\begin{tabular}{ccccc}
\hline & Variable & Number & Percentage & $\begin{array}{c}\text { Comparison of } \\
\text { Significance } \\
\text { P-value }\end{array}$ \\
\hline Duration of & $1^{\text {st }}$ trimester & 41 & $82 \%$ & 0.000 \\
pregnancy & $2^{\text {nd }}$ trimester & 9 & $18 \%$ & \\
& $3^{\text {rd }}$ trimester & 0 & 0 & 0.000 \\
Number of & First time & 6 & $12 \%$ & \\
abortion & Second time & 23 & $46 \%$ & \\
& Third time & 19 & $38 \%$ & 0.000 \\
\hline Parity & Fourth time & 2 & $4 \%$ & \\
& Nulliparaous & 5 & $10 \%$ & \\
& Primiparaous & 11 & $22 \%$ & \\
& Multiparaous & 31 & $62 \%$ & \\
\hline
\end{tabular}

Table 3. Positive and negative results for CMV and HHV-1 among studied group

\begin{tabular}{cccc}
\hline IHC results & $\begin{array}{c}\text { Positive } \\
\text { No. (\%) }\end{array}$ & $\begin{array}{c}\text { Negative } \\
\text { No. (\%) }\end{array}$ & $\begin{array}{c}\text { Comparison of Significance } \\
\text { P-value }\end{array}$ \\
\hline CMV & $18(36 \%)$ & $32(64 \%)$ & 1.000 \\
HHV-1 & $18(36 \%)$ & $32(64 \%)$ & \\
\hline
\end{tabular}




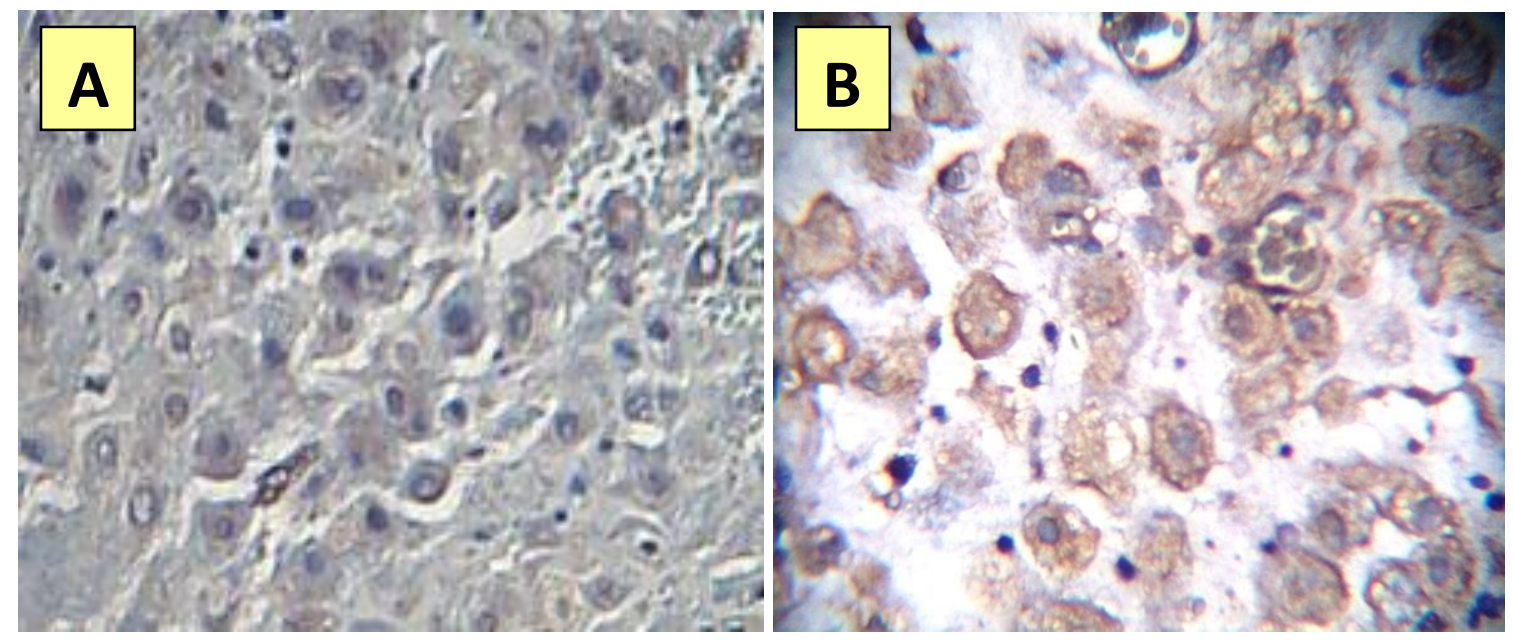

Figure 1. Immunohistochemistry for HCMV and HHV-1 in product of conceptus tissues of pregnant women with spontaneous abortion section, stained by DAB chromogen and counter stained with heamatoxylin is shown as radish brown in positive cases (magnification power, 400). A-HCMV positive expression, B- HHV-1 positive expression.

\section{Discussion}

Viral infections are more likely to occur at certain times in life such as childhood, adolescence and pregnancy. Pregnant women are at greatest risk of viral infection, due to the fact that they have defect in immune response. We chose in this study this segment of females for focus with a view two reasons the extent of the problem in our society. The idea was to investigate the viral infection rate among pregnant women with spontaneous abortion. Human cytomegalovirus is linked to late abortions and to stillbirth and reactivation of chronic HCMV infection in the course of pregnancy might result in fetal infection with spontaneous abortion (15-17). The current study had demonstrated that HCMV infection in pregnant women with spontaneous abortion was $36 \%$, this result is comparable with result of a study done in Erbil city, which found that the seropositivity was $30.05 \%{ }^{(18)}$. However, other studies showed higher rate than result of present study, which reported a detection rates ranged between $62.3 \%$ and $81.1 \%(19,20)$. When compare to studies conducted in Arabic countries such as Tunisia, where a $96.3 \%$ seroprevalence of HCMV antibody was reported among 404 Tunisian pregnant women (21). High frequency rate could therefore be related to a higher risk of infection, but it may also be related to use less sensitive diagnostic methods such as virus culture in certain areas compare with other technique. While the rate was lower in study done by el-Sayed and Goda that achieved $12 \%{ }^{(22)}$.

There is a $2 \%$ incidence of HHSV-1 or HHSV-2 infections among women during pregnancy ${ }^{(23) .}$ Herpes virus 1 accounts to about one-third to a half of cases of neonatal herpes ${ }^{(24,25)}$.

The result demonstrated that the frequency of HHV-1 was $36 \%$ in product of conceptus tissues of pregnant women with portentous abortion. Similar study carried out by Frenkel, et al., 1993 (26), who reported that HSV was detected by serology in $36 \%$ in pregnant women with no history of genital herpes. Also, this result was in agreement with the findings el-Sayed and Goda (2007) who reported that 40\% women with recurrent abortion have HSV IgM (22). Increased risk of spontaneous abortion, stillbirth, and congenital anomalies have always been associated with herpes virus ${ }^{(27)}$. 
Iraqi JMS 2017; Vol. 15(1)

Table 4. Distribution of positive and negative HCMV-IHC results according to socio-demographic and antenatal characteristics of study

\begin{tabular}{|c|c|c|c|c|}
\hline \multicolumn{2}{|c|}{ Variable } & \multirow{2}{*}{$\begin{array}{c}\begin{array}{c}\text { Positive } \\
\text { No. (\%) }\end{array} \\
6(33.33 \%)\end{array}$} & \multirow{2}{*}{$\begin{array}{c}\begin{array}{c}\text { Negative } \\
\text { No. (\%) }\end{array} \\
13(40.62 \%)\end{array}$} & \multirow{2}{*}{$\begin{array}{c}\text { Comparison of } \\
\text { Significance } \\
\text { P-value }\end{array}$} \\
\hline & $15-25$ & & & \\
\hline Age (year) & $26-35$ & $10(55.55 \%)$ & $9(28.12 \%)$ & 0.111 \\
\hline & $36-45$ & $2(11.11 \%)$ & $10(31.25 \%)$ & \\
\hline \multirow{4}{*}{ Education level } & Illiterate & $1(5.55 \%)$ & $7(21.87 \%)$ & \multirow{4}{*}{0.294} \\
\hline & Primary School & $13(72.22 \%)$ & $15(46.87 \%)$ & \\
\hline & Secondary School & 2 (11.11\%) & $4(12.50 \%)$ & \\
\hline & Tertiary level & 2 (11.11\%) & $6(18.75 \%)$ & \\
\hline \multirow{2}{*}{ Occupation } & Working & $2(11.11 \%)$ & $5(15.62 \%)$ & \multirow{2}{*}{0.659} \\
\hline & Housewives & $16(88.88 \%)$ & $27(84.37 \%)$ & \\
\hline \multirow{3}{*}{ Economic level } & Low & $3(16.66 \%)$ & $5(15.62 \%)$ & \multirow{3}{*}{0.508} \\
\hline & Intermediate & $13(72.22 \%)$ & $26(81.25 \%)$ & \\
\hline & High & $2(11.11 \%)$ & $1(3.12 \%)$ & \\
\hline \multirow{2}{*}{ Residence } & Urban & $15(83.33 \%)$ & $21(65.62 \%)$ & \multirow{2}{*}{0.181} \\
\hline & Rural & $3(16.66 \%)$ & $11(34.37 \%)$ & \\
\hline \multirow{3}{*}{$\begin{array}{l}\text { Duration of } \\
\text { pregnancy }\end{array}$} & $1^{\mathrm{St}}$ & $15(83.33 \%)$ & $26(81.25 \%)$ & \multirow{3}{*}{0.854} \\
\hline & $2^{\text {nd }}$ & $3(16.66 \%)$ & $6(18.75 \%)$ & \\
\hline & $3^{\text {rd }}$ & 0 & 0 & \\
\hline \multirow{4}{*}{$\begin{array}{c}\text { Number of } \\
\text { abortion }\end{array}$} & First time & $2(11.11 \%)$ & $4(12.5 \%)$ & \multirow{4}{*}{0.217} \\
\hline & Second time & 9 (50\%) & $14(43.74 \%)$ & \\
\hline & Third time & $5(27.77 \%)$ & $14(43.75 \%)$ & \\
\hline & Fourth time & $2(11.11 \%)$ & 0 & \\
\hline \multirow{4}{*}{ Parity } & Nulliparaous & $1(5.55 \%)$ & $4(12.5 \%)$ & \multirow{4}{*}{0.705} \\
\hline & primiparaous & $3(16.66 \%)$ & $8(25.0 \%)$ & \\
\hline & Multiparaous & $13(72.22 \%)$ & $18(56.25 \%)$ & \\
\hline & Gravid & $1(5.55 \%)$ & $2(6.25 \%)$ & \\
\hline
\end{tabular}

The results of current study showed the highest HCMV and HHV-1 infection rate among those enrolled cases at age interval between 15-35 years, cases of HSV-1 infections are seen worldwide and do not discriminate by age (28). Comparison of HCMV and HHV-1 positive results according to occupation and economical level, most positive cases occur within non-worker women and with intermediate economic level but no significant correlation occur among them. Human cytomegalovirus is found universally throughout all geographic locations and in all socioeconomic groups (19). Also, this result agrees with Pechaham et al. $2001^{(29)}$.

Although the present study revealed that the HCMV and HHV-1were highest in the first trimester, this result was consistent with those reported by other who found that the highest infection rate of HCMV and HHV-1 among aborted women ${ }^{(6,30)}$. Also, HHV found in the second trimester (27). While other study done 
by Skoczyński et al, (2015) who did not confirm the prenatal transmission of HPV and HSV during the investigation in 138 samples of amniotic fluid from pregnant women during the second trimester of gestation ${ }^{(31)}$. However, the damage is still more sever in infections occurring during the first half of pregnancy, while infections in the second half would result in reduced mortality ${ }^{(32)}$.

Table (5): Distribution of positive and negative human herpesvirus 1-IHC results according to socio-demographic and antenatal characteristics of study group

\begin{tabular}{|c|c|c|c|c|}
\hline \multicolumn{2}{|c|}{ Variable } & \multirow{2}{*}{$\begin{array}{c}\begin{array}{l}\text { Positive } \\
\text { No. (\%) }\end{array} \\
7(38.88 \%)\end{array}$} & \multirow{2}{*}{$\begin{array}{c}\begin{array}{c}\text { Negative } \\
\text { No. (\%) }\end{array} \\
12(37.5 \%)\end{array}$} & \multirow[t]{2}{*}{$\begin{array}{c}\text { Comparison of } \\
\text { Significance } \\
\text { P-value }\end{array}$} \\
\hline \multirow{3}{*}{ Age (year) } & $15-25$ & & & \\
\hline & $26-35$ & 7 (38.88\%) & $12(37.5 \%)$ & \multirow[t]{2}{*}{0.976} \\
\hline & $36-45$ & $4(22.22 \%)$ & $8(25.0 \%)$ & \\
\hline \multirow{4}{*}{ Education level } & Illiterate & $4(22.22 \%)$ & $4(12.5 \%)$ & \multirow{4}{*}{0.203} \\
\hline & Primary School & 7 (38.88\%) & $21(65.6 \%)$ & \\
\hline & Secondary School & $4(22.22 \%)$ & $2(6.25 \%)$ & \\
\hline & Tertiary level & $3(16.66 \%)$ & $5(15.62 \%)$ & \\
\hline \multirow{2}{*}{ Occupation } & Working & $2(11.11 \%)$ & $5(15.62 \%)$ & \multirow{2}{*}{0.956} \\
\hline & Housewives & $16(88.88 \%)$ & $27(84.37 \%)$ & \\
\hline \multirow{3}{*}{ Economic level } & Low & $4(22.22 \%)$ & $4(12.5 \%)$ & \multirow{3}{*}{0.667} \\
\hline & Intermediate & $13(72.22 \%)$ & $26(81.25 \%)$ & \\
\hline & High & $1(5.55 \%)$ & $2(6.25 \%)$ & \\
\hline \multirow{2}{*}{ Residence } & Urban & $14(77.77 \%)$ & $22(68.75 \%)$ & \multirow{2}{*}{0.495} \\
\hline & Rural & $4(22.22 \%)$ & $10(25.0 \%)$ & \\
\hline \multirow{3}{*}{$\begin{array}{l}\text { Duration of } \\
\text { pregnancy }\end{array}$} & $1^{\text {St }}$ & $16(88.88 \%)$ & $25(78.12 \%)$ & \multirow{3}{*}{0.459} \\
\hline & $2^{\text {nd }}$ & $2(11.11 \%)$ & 7 (21.87\%) & \\
\hline & $3^{\text {rd }}$ & 0 & 0 & \\
\hline \multirow{4}{*}{$\begin{array}{l}\text { Number of } \\
\text { abortion }\end{array}$} & First time & $2(11.11 \%)$ & 4 (12.5\%) & \multirow{4}{*}{0.848} \\
\hline & Second time & 7 (38.88\%) & 16 (50.0\%) & \\
\hline & Third time & $8(44.44 \%)$ & 11 (34.37\%) & \\
\hline & Fourth time & $1(5.55 \%)$ & $1(3.12 \%)$ & \\
\hline \multirow{4}{*}{ Parity } & Nulliparaous & 2 (11.11\%) & $3(9.37 \%)$ & \multirow{4}{*}{0.694} \\
\hline & primiparaous & $4(22.22 \%)$ & 7 (21.87\%) & \\
\hline & Multiparaous & $10(55.55 \%)$ & $21(65.62 \%)$ & \\
\hline & Gravid & $2(11.11 \%)$ & $1(3.12 \%)$ & \\
\hline
\end{tabular}

In the current study, there is no significant correlation between the HCMV and HHV-1 infection in aborted pregnant women with age, education level, occupation, economic level, residence, gestational age, history of abortions and parity; so, these cannot be considered as risk factors for infection.
The differences between the results of the previously mentioned studies and even with the results of present study could be related to many factors, like the methodology in the current study used molecular technique while other study may use serological methods, sample size, studied population different from one area to another, the duration of incubation 
if samples collect in acute infection the result will different from chronic infection, individual's immune status, demographic and geographical variations season and etc.

The current study concludes that viral infections with HCMV and HHV-1 might play a role in recurrent abortions. A cytomegalovirus and human herpesvirus-1 antigen is comparable with that in the other countries, and pregnant women in Baqubah city may have the risk for acquiring viral infection during pregnancy and consequently adverse pregnancy outcomes. Careful investigation for such conditions must involve detecting the presence of these viruses. Further investigation is needed with large sample size to clarify this issue and studying the role of other viruses in the pregnant women such as parvovirus.

\section{Acknowledgments:}

Authors like to express their thanks to all patients were included in this study.

\section{Author contributions:}

Authors participate in drafting the article and revising it critically for important intellectual content.

\section{Conflict of interest:}

The authors report no conflicts of interest.

\section{Funding:}

Self-funding.

\section{References}

1. Hurt KJ, Guile MW, Bienstock JL, et al. The Johns Hopkins manual of gynecology and obstetrics. $4^{\text {th }}$ ed. Lippincott Williams and Wilkins. 2012. p. 438-9.

2. http://www.nichd.nih.gov/.What is pregnancy loss/miscarriage. Retrieved 14 March 2015.

3. Atik RB, Hepworth-Jones BE, Doyle PA. Risk factors for miscarriage. In: Farquharson RG, Stephenson MD (eds). Early Pregnancy. Cambridge, UK: Cambridge University Press; 2010. p. 9-18.

4. Chow $S$, Craig $M$, Jacques $C$. Correlates of placental infection with cytomegalovirus, parvovirus B19 or human herpes virus 7. J Med Virol 2006; 78: 747-56. doi: 10.1002/jmv.20618.

5. Kim ID, Chang HS, Hwang KJ. Herpes simplex virus 2 infection rate and necessity of screening during pregnancy: A clinical and seroepidemiologic study.
Yonsei Med J. 2012; 53(2): 401-7. doi: 10.3349/ymj.2012.53.2.401.

6. Zhou, Ya, Guohui B, Qiongxiu Z, et al. Detection of cytomegalovirus, human parvovirus B19, and herpes simplex virus-1/2 in women with first-trim ester spontaneous abortions. J Med Virol. 2015; 87(10): 1749-53. doi: 10.1002/jmv.24218.

7. Lynch DP. Oral manifestation of viral diseases. In: Tyring SK (ed). Mucosal immunology and virology. London: Springer; 2006. p. 99-105.

8. Dollard SC, Grosse SD, Ross DS. New estimates of the prevalence of neurological and sensory sequelae and mortality associated with congenital cytomegalovirus infection. Rev Med Virol. 2007; 17: 355-63. doi: 10.1002/rmv.544.

9. Fowler KB, Stagno S, Pass RF. Maternal immunity and prevention of congenital cytomegalovirus infection. JAMA. 2003; 289: 1008-11.

10. Wang $C$, Zhang $X$, Bialek $S$, et al. Attribution of congenital cytomegalovirus infection to primary versus non-primary maternal infection. Clin Infect Dis. 2011; 52: e11-e13. doi: 10.1093/cid/ciq085.

11. Cusini, M, Ghislanzoni M. The importance of diagnosing genital herpes. J Antimicrob Chemother. 2001; 47 Suppl T1: 9-16.

12. Straface G, Selmin A, Zanardo V, et al. Herpes simplex virus infection in pregnancy. Infect Dis Obstet Gynecol. 2012; 2012: 385697. doi: 10.1155/2012/385697.

13. Bujko, M, Sulovic V, Zivanovic V. Herpes simplex virus infection in women with previous spontaneous abortion. J Perinat Med. 1988; 16(3): 193-6.

14. Sifakis, S, Koumantakis E, Koffa M. Detection of herpes simplex virus (HSV) in aborted material using the polymerase chain reaction technique. Gynaecol Obstet Invest. 1998. 45: 109-15.

15. Clewley JP. Polymerase chain reaction assay of parvovirus B19 DNA in clinical specimens. J Clin Microbiol. 1989; 27(12): 2647-51.

16. Szkaradkiewicz A, Pieta P, Tulecka T. The diagnostic value of anti-CMV and anti HPV, B19 antiviral antibodies in studies on causes of recurrent abortions. Ginekol Pol. 1997; 68 (4): 181-6.

17. Kenneson A, Cannon MJ. Review and meta-analysis of the epidemiology of congenital cytomegalovirus (CMV) infection. Rev Med Virol. 2007; 17: 253-76. doi: 10.1002/rmv.535.

18. Ali SA, Sharef TY. Serological study of cytomegalovirus (CMV) in spontaneous abortion. Zanco J Med Sci. 2007; 11(1): 31-6.

19. Munro SC, Hall B, Whybin LR, et al. Diagnosis of and screening for cytomegalovirus infection in pregnant women J Clin Microbiol. 2005; 43(9): 4713-8. doi: 10.1128/JCM.43.9.4713-4718.2005.

20. Odland J $\varnothing$, Sergejeva IV, Ivaneev MD. Seropositivity of cytomegalovirus, parvovirus and rubella in pregnant women and recurrent aborters in Leningrad country, Russia. Acta Obstetricia Gynecol Scand. 2001; 80: 1025-30. 
21. Hannachi N, Marzouk M, Harrabi I, et al. Seroprevalence of rubella virus, varicella zoster virus, cytomegalovirus and parvovirus B19 among pregnant women in the Sousse region, Tunisia. Bull Soc Pathol Exot. 2011; 104(1): 62-7. doi: 10.1007/s13149-0100119-z.

22. el-Sayed ZM, Goda H. Relevance of parvovirus B19, herpes simplex virus 2, and cytomegalovirus virologic markers in maternal serum for diagnosis of unexplained recurrent abortions. Arch Pathol Lab Med. 2007, 131(6): 956-60. doi: 10.1043/15432165(2007)131[956:ROPBHS]2.0.CO;2.

23. Brown ZA, Selke S, Zeh J, et al. The acquisition of herpes simplex virus during pregnancy. $N$ Engl J Med 1997; 337: 509-15. doi: 10.1056/NEJM199708213370801.

24. Brown ZA, Wald A, Morrow RA, et al. Effect of serologic status and cesarean delivery on transmission rates of herpes simplex virus from mother to infant. JAMA. 2003; 289: 203-9.

25. Whitley R, Arvin A, Prober C, et al. Infectious diseases collaborative antiviral study group. A controlled trial comparing vidarabine with acyclovir in neonatal herpes simplex virus infection. N Engl J Med. 1991; 324(7): 444-9. doi: 10.1056/NEJM199102143240703.

26. Frenkel, L M, Garratty EM, Shen JP. Clinical reactivation of herpes simplex virus type 2 infection in seropositive pregnant women with no history of genital herpes. Ann Intern Med. 1993; 118: 414-8.
27. Money D, Steben M, Infectious Diseases Committee, Society of Obstetricians and Gynecologists of Canada. Guidelines for the management of herpes simplex virus in pregnancy. J Obstet Gynaecol Can. 2008; 30(6): 514-26.

28. Malm G. Neonatal herpes simplex virus infection. Semin Fetal Neonatal Med. 2009; 14(4): 204-8. doi: 10.1016/j.siny.2009.01.005.

29. Pechaham C, Tookey P, Logan S, et al. Screening options for prevention congenital cytomegalovirus infection. J Med Screen. 2001; 8: 119-24. doi: 10.1136/jms.8.3.119.

30. Kapranos NC, Kotronias DC. Detection of herpes simplex virus in first trimester pregnancy loss using molecular techniques. In Vivo. 2009; 23(5): 839-42.

31. Skoczyński M, Krzyżanowski AR, Goździcka-Józefiak A, et al. Prevalence of human papillomavirus and herpes simplex virus in amniotic fluid from pregnant women of Eastern Poland. Postepy Hig Med Dosw (Online). 2015; 69: 1349-52.

32. Sinclair J, Sissons P. Latency and reactivation of human cytomegalovirus. J Gen Virol. 2006; 87(Pt 7): 1763-79. doi: 10.1099/vir.0.81891-0.

Correspondence to Dr. Areej A. Hussein
E-mail: areej.2002@yahoo.com
Received 11 $1^{\text {th }}$ Aug. 2016
Accepted 20
th Dec. 2016

